Article

\title{
The Effect of Housing Prices on Bank Performance in Korea
}

\author{
Youngkyung $\mathrm{Ok}^{1}{ }^{1}$, Jungmu Kim ${ }^{2} \mathbb{D}$ and Yuen Jung Park ${ }^{3, *}$ \\ 1 DGB Research Institute, Daegu 41593, Korea; okggaeng0208@gmail.com \\ 2 Department of Business Administration, Yeungnam University, Gyeongsan 38541, Korea; jungmu@yu.ac.kr \\ 3 Department of Finance, College of Business, Hallym University, Chuncheon 24252, Korea \\ * Correspondence: yjpark@hallym.ac.kr
}

Received: 1 October 2019; Accepted: 4 November 2019; Published: 7 November 2019

check for updates

\begin{abstract}
This study analyzes the relationship between housing prices and bank performance in Korea. To this end, using lending growth, return on assets, and non-performing loans as a performance measure, we estimate fixed-effects models for each measure. Major empirical results are summarized as follows. First, fluctuations in housing prices affect the banks' lending decisions. If housing prices rise, banks tend to increase the volume of loans. Second, fluctuations in housing prices affect the quality of assets owned by banks. Banks' asset soundness will improve in the case of a rise in housing prices. Third, fluctuations in housing prices have a greater impact on bank profitability when the real estate market goes bust. Our study suggests that in Korea, one of the emerging markets, there is a positive relationship between changes in housing prices and banks' performance. In particular, banks' profitability and soundness could be significantly hampered by a drop in housing prices. Therefore, it is necessary to be wary of excessively expanding real estate loans during the period of real estate booms.
\end{abstract}

Keywords: bank performance; fixed effect model; granger causality; housing price; sustainability

\section{Introduction}

Understanding the price fluctuations in the real estate market is of importance because fluctuations in real estate prices have a significant impact on the soundness and profitability of the banking sector. One extreme case of the impact can be seen in the recent financial crisis caused by defaults on subprime mortgage loans in the United States [1-3]. In 2007, a significant drop in the United States housing prices caused subprime mortgage loans to start defaulting, and it eventually became a reason for a global financial crisis. As seen in this spiral effect, the reason that the real estate market sustainability is highly influential on banking sector sustainability is that banks not only own real estate as assets but also engage in mortgage lending [4].

Generally, banks ask for collateral when offering loans, rather than making an effort to evaluate potential borrowers themselves. Banks make lending decisions based on the collateral borrowers provide [5]. There is no way for a bank to force a loan repayment unless the borrower provides collateral [6]. Even if the borrower fails to repay the loan, if the value of the real estate rises, the recovery rate is very high [1]. Thus, real estate is mainly used as collateral [7]; banks determine the interest rate of the loan according to the value of the collateral assets such as quality, liquidity, and price volatility provided as collateral. In addition, the credit market is an imperfect market in which information asymmetry exists between the lender and the borrower, the collateral plays a role in preventing the moral hazard of the borrower.

The value of general assets is estimated by discounting the expected cash flows from the assets. For example, if a bank wants to extend the volume of lending and the borrower can borrow at a lower 
interest rate, then the present value of the real estate may increase as the discount rate decreases [7]. This process considers not only the interest rate on loans, but also macroeconomic fundamentals such as GDP growth rate, price level, and business cycles.

However, there are some unique characteristics that distinguish real estate from other assets. Real estate is a non-standardized asset that differs from other assets in quality and is clearly geographically segmented. There is also no standardized exchange or central trading hub. These characteristics increase information asymmetry between buyers and sellers and leave a margin for price negotiation. In this process, high transaction costs will occur. Another distinguishing feature of real estate is the difficulty in responding promptly to supply responses because of constraints such as having to look for suitable sites and long construction periods $[4,8]$. In addition, real estate prices are significantly affected by government policies and loan regulations [9]. Thus, there is a possibility that the economic logical relationship which applies to other assets weakens in case of real estate.

Under these conditions, fluctuations in real estate prices can affect the bank performance in two ways. First, an increase in real estate prices increases the value of bank assets, thereby increasing the value owned by the bank and held as collateral. It reduces the probability of falling into financial distress by lowering the risk on bank assets. This is the so-called collateral value hypothesis. The rise in real estate prices will raise bank stability and lower the probability of default $[2,5,10]$.

Conversely, increasing real estate prices may also increase banks' risk. Moral hazard and the problem of adverse selection can be induced [11]. If real estate prices increase, risky borrowers who assume that prices will continue to rise demand additional credit. If banks also believe that real estate prices will continue to rise, they may issue a loan at unreasonably low interest rates. Banks believe that the risk associated with mortgage lending is low. In this case, if the price of real estate reverses, the bank is in danger of being in financial trouble; this is known as the deviation hypothesis [12]. If real estate prices deviate excessively from fundamentals and the price volatility increases, banks' probability of default also increases. As such, fluctuations in real estate prices can have both positive and negative impact on the bank performance.

Despite the great impact of housing price fluctuations on bank performance, it is unclear whether the rise in real estate prices leads to an increase in bank lending or vice versa. The rise in mortgage value because of the rise in real estate prices may lead to an increase in bank lending. On the other hand, sufficient liquidity because of the expansion of bank lending and an increase in real estate demand could lead to an increase in real estate prices [6,12]. Otherwise, optimistic expectations for future economic conditions may lead to an increase in real estate prices [7].

In most countries, residential real estate is a larger part of the national economy. Residential real estate accounts for the largest part of household net wealth and accounts for $30 \%$ of the world wealth, greater than bonds or stocks [13]. As a house is one of the most expensive consumer goods, households have to rely on bank lending to buy a house. As a mortgage lender, banks are sensitive to changes in property prices. If borrowers fail to repay loans, banks' default risk will increase.

Korea is no exception to this phenomenon. The proportion of real estate accounts for two-thirds of household total assets [14]. This figure is much higher than other developed countries. Because of the high proportion of real estate, the Korean banking industry may therefore be more sensitive to changes in real estate prices. Therefore, the Korean government is making efforts to stabilize real estate prices by implementing various real estate policies. The real estate policy in Korea is divided into two categories [15]. One is a price stabilization policy to prevent overheating of the market and the other is an active economic stimulus policy to recover a sluggish market. Specifically, in terms of price stabilization, demand control policies are mainly used such as trade regulation, tax strengthening, and financial regulation. Second, the economic stimulus policy includes easing regulations and vitalizing demand through funding and tax support. Since the first real estate policy in 1967, the government has issued more than 60 real estate-related policies, but nonetheless, the real estate market in Korea has been very unstable [15-17]. It is possible to expect that the stability and performance of banks will be very 
unstable because of such unstable housing prices in Korea. For this reason, it is very meaningful to examine the effect of real estate price changes on bank performance in Korea.

In this paper, we empirically analyze the relationship between housing price fluctuations and the bank performance in Korea. The first goal is to identify the causal relationship between changes in housing prices and bank lending. It is well-known that there is a positive correlation between real estate prices and bank lending in both developed and developing countries [12]. It is also reported that financial and housing markets in Korea have been highly correlated since the financial crisis of 1997, when deregulation and financial liberalization began [14]. However, the direction of causality between the two variables is not clear. Thus, we examine whether changes in housing prices could cause an increase in the volume of bank lending or vice versa.

Next, we examine whether fluctuations in housing prices have a significant effect on bank performance. As the proportion of real estate mortgage loans in banks' total loans increases, changes in the value of real estate mortgage loans and of collateral assets will impact the bank performance. In addition, interest income from real estate loans which account for a large portion of bank's total profits also directly improves banks' performance [17]. Thus, we investigate the effect of real estate price changes on bank performance using return on assets (ROA), which is a measure of profitability, and non-performing loans (NPL), which is a measure of asset soundness.

The main findings are as follows. First, changes in housing prices affect bank lending decisions. If housing prices increase, banks increase their lending. Pro-cyclicality becomes more prominent in regional banks. In fact, the decline in housing prices is enough incentive for banks to reduce their loans. If housing prices fall, it will increase bad loans, which should add additional loan loss provision. In this case, banks will be forced to reduce the capital ratio by reducing risky assets [18]. Second, changes in housing prices affect banks' asset quality. If housing prices rise, banks' asset soundness will improve. As the value of collateral rises, the bad loan ratio (non-performing loans) is reduced. This is a consistent phenomenon regardless of the real estate business cycle. Third, changes in housing prices have a greater impact on bank profitability during real estate business recession than during booms. Because of the lending competition in a real estate business boom, bank profitability is unlikely to improve. However, profitability will deteriorate severely because of the deterioration of existing loan assets while new loans are decreasing during a recession [17].

The financial sector has a relatively high entry barrier. Excessive competition among financial institutions may cause risky investment, resulting in large-scale insolvency and financial market instability. When the banking industry takes a hit, the entire national economy is threatened. Therefore, securing the profitability and soundness of banks is very important. Only the sustainable growth of banks can guarantee the sound development of the national economy. In this context, this study is meaningful in that it analyzes the relationship between the changes in housing prices, which account for a large portion of the national economy, and the sustainable growth of banks.

This study has the following limitations. Because of limitations in data availability, the analysis period begins from 2000; it is necessary to extend the research period with long-term data. In addition, housing price fluctuations may vary by region. It would be more meaningful to be able to utilize local real estate price data and local real estate loan information.

The remainder of this paper is organized as follows. We review the relevant literature in Section 2. Section 3 describes the data and empirical methodology. Section 4 provides empirical results. Finally, Section 5 provides concluding remarks.

\section{Literature Review}

Banks play an important role in financing real estate projects as lenders. Thus, because of the important role of banks as lenders, it is not surprising that there is a correlation between fluctuations in real estate prices and bank performance. Extensive studies have been conducted in the past decade, and interest in this field has been increasing. However, commercial and residential real estate cannot be analyzed together because they have different business cycles and interact differently with the 
financial system or the real economic situation [19]. Thus, previous studies either analyze commercial properties or residential properties.

There is significant evidence on the relationships between residential property prices and bank performance. Gerlach and Peng [12] argue that property prices are closely correlated with bank lending. Specifically, residential property prices adjust bank lending in Hong Kong, rather than vice versa. This phenomenon is more strongly significant in banks that have higher proportion of real estate loans. Blaško and Sinkey [20] document that since the 1990s, commercial banks have moved their assets to real estate loans. They find that less-specialized banks that hold $40 \%$ or more of their total assets as secured real estate loans have a higher insolvency probability. Goodhart and Hofmann [21] examine the interaction between housing price, money, credit, and macroeconomy. They argue that there are multidirectional relationships between all these variables. Money growth influences housing prices and credit, credit affects money and housing prices, and house price also affects credit and money. Koetter and Poghosyan [4] also find that the deviation of real estate prices tends to be negatively associated with bank instability, but not with price level changes. Pan and Wang [2] argue that residential property price changes have a negative impact on banks' NPL. As housing prices rise, the NPL ratio falls. In addition, this phenomenon is stronger during an economic boom rather than bust. At this time, the stability of banks could deteriorate. Hott [3] argues that although changes in real estate prices may hurt banks, banks decisions ultimately cause real estate price changes because bank loans create property bubbles. Che et al. [7] argue that bank loans play a crucial role in increasing property prices in China; as banks increase loans, property prices rise. Zhang et al. [1] also investigated the Chinese property market. They suggest that regional banks' profits stem from the rapid increase in real estate investment. Therefore, when the housing market is in recession, bank stability is weakened; the housing market downturn raises banks' NPL.

There is relatively limited evidence on whether commercial property prices are related to bank performance. Davis and Zhu [9] argue that commercial property prices are closely related to bank performance at the micro level. Specifically, there is a positive relationship between commercial property prices and bank profitability, and a negative relationship between net interest margin and bad loan ratios. This phenomenon is consistent even after controlling for various factors that are known to affect the bank performance. Moreover, the relationship is positively related to the size of the bank. In an empirical study of 17 countries, Davis and Zhu [19] argue that property prices have a strong correlation with bank lending; there is a positive relationship in the short-term, but the long-term relationship is negative.

Some studies analyze both commercial and residential real estate. Arpa et al. [22] suggested that real estate prices are positively related with the operating income of banks in Austria. Rising housing prices should increase the profitability of real estate subsidiaries held by banks. In addition, rising housing prices increase demand for mortgage loans, which improves bank profitability. He et al. [23] argue that that banks' stock returns are very sensitive to changes in total real estate returns such as construction and development, residential, and nonresidential loans.

To assess the impact of real estate price fluctuations on a bank's performance, we choose testing variables based on the literature as follows. The most widely used variable to measure bank performance is NPL [1,2,24-27]. ROA is also a very popular measure to assess bank performance [28-35]. Other variables are bank failure rates [36,37], net interest margin [38], growth in loans [39], and probability of distress events [4].

Studies on bank performance either focus on a single country [33-35,40-44] and or on a panel of countries [32,45-48]. Many focus mainly on developed countries such as the United States and Europe, and there are very few studies on emerging countries and Asia. We fill this gap by analyzing the economy of Korea which can be regarded as a leading market of emerging countries. 


\section{Data and Methodology}

The purpose of this study is to examine whether fluctuations in real estate prices affect bank lending decisions and performance. To do this, we estimate Model (1). We construct a fixed effects model to estimate Model (1).

$$
y_{i, t}=\alpha_{0}+\beta_{H} H G R_{t}+\beta_{M} M A C R O_{t}+\beta_{F} F_{R I} M_{i, t}+\epsilon_{i, t}
$$

where $y_{i, t}$ denotes bank performance, which is calculated using the lending growth rate (LG), ROA, and non-performing loans (NPL). Loan growth rate is calculated as the growth rate of the loan against the same period of the previous year. ROA is calculated by dividing net income before income tax by total assets (average). The ratio of bad loans is calculated by dividing the assets classified as doubtful and estimated losses by the total assets. $H G R_{t}$ (housing price growth rate), which is a main variable in this study is a proxy for housing price fluctuation and is calculated as the year-on-year growth rate of the home price index announced by the Korea Appraiser Board. The real estate market in Korea can be divided into residential real estate and commercial real estate [49]. Residential real estate is primarily privately owned and evenly distributed throughout the country. Commercial real estate, on the other hand, is primarily owned by companies and concentrated in urban areas. In addition, unlike commercial real estate, where the income from rent is invested, apartments are aimed at capital gains as prices rise. Therefore, in order to observe the impact of changes in real estate prices, housing prices is mainly used rather than other variables such as land price, rent, and commercial real estate fluctuations $[17,18] . M A C R O_{t}$ represents macroeconomic variables that include call rate, GDP growth rate (GDPGR), and consumer price index growth rate (CPIGR). FIRM $M_{i, t}$ is the characteristic variable of individual bank $i$. The characteristics of individual banks include the following variables. First, the capital ratio (CAPR) is calculated by dividing the capital by total assets. This is a variable for measuring the lending ability of the bank in terms of financing. Loan ratio (LOANR) is calculated by dividing the loan by total assets. It measures the risk exposure of bank loans. Interest revenue (INR) is calculated by dividing the interest income by operating income. It is an indicator for determining the proportion of interest income in bank operating income. Loan constitution (LOANCONS) is calculated by dividing business loans by household loans. This is an indicator for measuring the relative risk of household lending.

Only commercial banks and regional banks are included in our sample and specialized banks are excluded. The number of banks, which was close to 30 before the financial crisis in 1997, decreased to 12 by 2018. As of December 2018, the number of commercial and regional banks is six. Mergers between banks have been steadily taking place to strengthen bank competitiveness after the financial crisis of 1997. The data are obtained from Statistics Korea, Korea Appraisal Board, and the Financial Statistics Information System of the Financial Supervisory Service. The sample period is from 2000 to 2018.

Table 1 reports the summary statistics. Panel A presents the results for the whole sample, while Panel B reports the results for commercial and regional banks. Panel A reveals that the housing price index increased by about $3.96 \%$ per annum during the sample period. Although it is higher than the CPI growth rate, it is lower than the GDPGR. Panel B shows that the loan growth rate, loan ratio, interest revenue, and loan constitution of regional banks are higher than those of commercial banks. This indicates that regional banks are lending more to risky borrowers. 
Table 1. Summary statistics.

\begin{tabular}{|c|c|c|c|c|c|c|c|}
\hline & Mean & Std & MIN & Q1 & MED & Q3 & MAX \\
\hline \multicolumn{8}{|c|}{ Panel A: Whole Sample } \\
\hline HGR & 3.96 & 4.52 & -2.07 & 1.23 & 3.11 & 5.74 & 16.43 \\
\hline \multicolumn{8}{|l|}{ Macro } \\
\hline CALL & 3.13 & 1.32 & 1.27 & 2.01 & 3.02 & 4.00 & 6.01 \\
\hline GDPGR & 4.05 & 1.97 & 0.70 & 2.80 & 3.30 & 5.20 & 8.90 \\
\hline CPIGR & 2.48 & 1.10 & 0.83 & 1.34 & 2.78 & 3.42 & 4.16 \\
\hline \multicolumn{8}{|l|}{ Firm Specific } \\
\hline LG & 10.63 & 6.95 & 3.47 & 5.55 & 9.15 & 14.48 & 30.97 \\
\hline ROA & 0.55 & 0.35 & -0.60 & 0.40 & 0.56 & 0.70 & 1.08 \\
\hline NPL & 0.85 & 1.13 & 0.32 & 0.38 & 0.49 & 0.81 & 5.25 \\
\hline CAPR & 6.50 & 1.54 & 3.99 & 4.94 & 6.49 & 8.02 & 8.24 \\
\hline LOANR & 58.48 & 7.27 & 42.40 & 56.70 & 58.15 & 63.90 & 68.52 \\
\hline INR & 61.68 & 10.45 & 40.28 & 53.86 & 60.03 & 69.54 & 77.08 \\
\hline LOANCONS & 159.88 & 36.11 & 119.21 & 136.77 & 154.99 & 165.63 & 275.38 \\
\hline \multicolumn{8}{|c|}{ Panel B: By Group } \\
\hline \multicolumn{8}{|l|}{ Commercial Bank } \\
\hline LG & 9.49 & 9.25 & -1.09 & 3.91 & 5.19 & 11.21 & 33.68 \\
\hline ROA & 0.54 & 0.34 & -0.23 & 0.34 & 0.55 & 0.73 & 1.23 \\
\hline NPL & 0.96 & 1.23 & 0.30 & 0.43 & 0.57 & 0.77 & 5.61 \\
\hline CAPR & 6.91 & 1.67 & 4.40 & 4.88 & 6.92 & 8.58 & 8.74 \\
\hline LOANR & 54.63 & 5.58 & 40.68 & 53.07 & 56.12 & 57.99 & 60.44 \\
\hline INR & 45.36 & 16.75 & 19.60 & 32.42 & 41.99 & 57.07 & 72.51 \\
\hline LOANCONS & 94.05 & 32.39 & 71.15 & 73.74 & 85.59 & 93.32 & 202.85 \\
\hline \multicolumn{8}{|l|}{ Regional Bank } \\
\hline LG & 11.72 & 5.63 & 2.06 & 8.11 & 10.49 & 13.78 & 28.25 \\
\hline ROA & 0.54 & 0.47 & -1.23 & 0.49 & 0.67 & 0.81 & 0.89 \\
\hline NPL & 0.72 & 0.98 & 0.29 & 0.33 & 0.41 & 0.75 & 4.65 \\
\hline CAPR & 6.04 & 1.45 & 3.51 & 5.01 & 6.25 & 7.43 & 7.89 \\
\hline LOANR & 62.66 & 9.15 & 45.26 & 57.62 & 62.74 & 70.80 & 76.59 \\
\hline INR & 80.34 & 5.44 & 64.40 & 78.51 & 81.78 & 84.70 & 86.16 \\
\hline LOANCONS & 235.99 & 50.86 & 165.49 & 203.75 & 225.69 & 257.14 & 396.26 \\
\hline
\end{tabular}

Note: housing price growth rate (HGR), call rate (CALL), GDP growth rate (GDPGR), consumer price index growth rate (CPIGR), lending growth rate (LG), return on assets (ROA), non-performing loans (NPL), capital ratio (CAPR), loan ratio (LOANR), interest revenue (INR), loan constitution (LOANCONS).

\section{Empirical Results}

In this section, we analyze the impact of housing price changes on banks' lending decisions and performance. We conduct the fixed effects model using panel data and check the sign, magnitude, and significance of the regression coefficients. All variables are estimated following the definitions in Section 3.

\subsection{Time-Series Patterns of Housing Prices, Bank Lending, and Bank Performances}

Figure 1 shows the time-series patterns of housing prices, bank lending, ROA, and NPL. The loan growth rate and ROA move in the same direction as housing prices, while NPL moves in the opposite direction. When housing prices are high, banks increase their lending to improve profitability and asset quality. The soundness of assets is also strengthened.

However, the direction of the relationship is unclear as to whether fluctuations in housing prices affect the volume of bank loans or, conversely, increases in bank loans cause fluctuations in housing prices. The Granger causality test was conducted to clarify the direction of the causal relationship. The results are reported in Table 2. The results indicate that the increase in bank lending has led to a rise in housing prices. Especially, for commercial banks, the change in bank lending granger-causes the housing price change with a lag of two quarters. If liquidity becomes abundant in the market, the price 
of house will rise. This is why the government regulates bank lending to stabilize housing prices. This is consistent with the findings of Liang and Cao [50] and Che et al. [7], who analyzed China. They argued that the increase in bank lending leads to fluctuations in real estate prices.

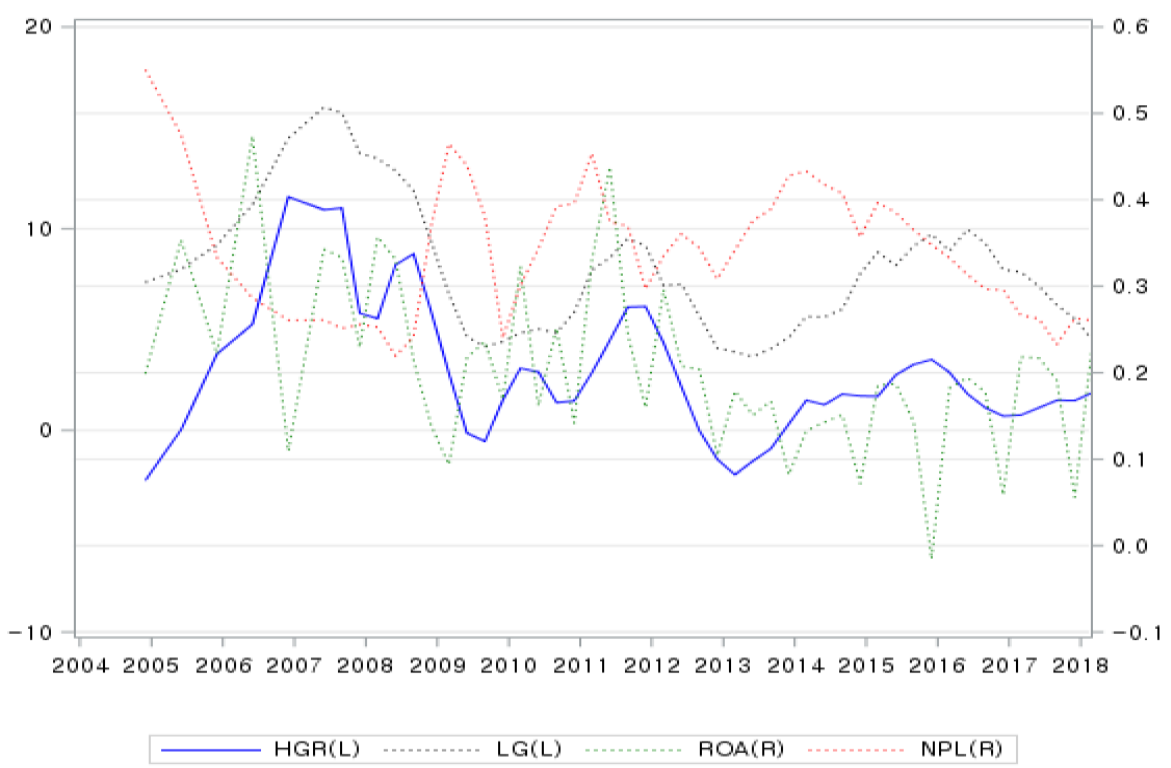

Figure 1. Time-series of the real estate prices and bank performance.

Table 2. The result of Granger causality tests.

\begin{tabular}{ccccc}
\hline & \multicolumn{4}{c}{ Lags } \\
\cline { 2 - 4 } & $\mathbf{1}$ & $\mathbf{2}$ & $\mathbf{3}$ & $\mathbf{4}$ \\
\hline \multicolumn{5}{c}{ Panel A: Whole Sample } \\
\hline LG $\nrightarrow$ HGR & 0.723 & 10.671 & 7.046 & 5.239 \\
& $(0.398)$ & $(0.000)$ & $(0.000)$ & $(0.001)$ \\
HGR $\nrightarrow$ LG & 6.251 & 3.216 & 0.855 & 1.893 \\
& $(0.015)$ & $(0.047)$ & $(0.469)$ & $(0.123)$ \\
\hline & Panel B: Commercial Bank & \\
\hline LG $\nrightarrow$ HGR & 2.430 & 10.989 & 6.908 & 4.596 \\
& $(0.124)$ & $(0.000)$ & $(0.000)$ & $(0.003)$ \\
HGR $\nrightarrow$ LG & 2.876 & 3.607 & 1.966 & 3.140 \\
& $(0.094)$ & $(0.033)$ & $(0.128)$ & $(0.021)$ \\
\hline & Panel C: Regional Bank \\
\hline LG $\nrightarrow$ HGR & 8.094 & 1.230 & 0.542 & \\
& $(0.006)$ & $(0.299)$ & $(0.655)$ & $(0.844)$ \\
HGR $\nrightarrow$ LG & 2.150 & 6.186 & 3.503 & 3.369 \\
& $(0.147)$ & $(0.003)$ & $(0.020)$ & $(0.015)$ \\
\hline
\end{tabular}

Note: housing price growth rate (HGR), lending growth rate (LG). $p$-values are in parentheses.

This effect is reversed for regional banks in that fluctuations in housing prices are shifting the bank loans. This result is consistent with the findings of Gerlach and Peng [12]. They showed that causality is from residential property prices to bank credit. Pro-cyclicality becomes more prominent in regional banks. In fact, the decline in housing prices is enough incentive for banks to reduce their loans. If housing prices fall, it will increase bad loans, which should add additional loan loss provision. In this case, banks will be forced to reduce the capital ratio by reducing risky assets [18]. The phenomenon is more prominent in regional banks. In the case of regional banks, the proportion of corporate loans is higher than that of household loans. Under this situation, lending to household is likely to expand 
more rapidly as housing prices rise. The real estate market is currently relatively stable. If housing prices rise, the bank will extend their loans and if housing prices fall, loans will be reduced.

\subsection{Bank Performance on Housing Prices Fluctuations}

Tables 3-5 report regression results. Model (1) shows the effects of changes in housing prices on bank lending growth (LG) and bank performance without controlling the other factors. Model (2) examines the impact of changes in real estate prices after controlling for macroeconomic conditions. Model (3) captures the impact of changes in real estate prices after controlling for the various factors known to affect the bank performance. In Model (4), we control for all aforementioned variables. Finally, Model (5) confirms whether the effect of real estate price change is differentiated by the proportion of mortgage loans from the bank. It uses the cross-term of mortgage-loan ratio and real estate price change instead of real estate price changes.

First, we report the impact of changes in real estate prices on loan growth rates in Table 3. The coefficient of HGR in Model (1), which does not control other factors is 1.11, which is statistically significant at the $1 \%$ level. This is consistent with previous studies showing that there is a positive correlation between changes in housing prices and the loan growth rate [46,47]. The relationship is found to be consistent even after including control variables. The magnitude and significance of the regression coefficient are slightly lower after controlling for other factors but are still statistically significant at the $1 \%$ level. Housing prices have a positive impact on bank lending growth. If the price of house increases, the loan growth rate of banks increases. This relationship is differentiated by the proportion of real estate mortgage loans held by banks. The coefficient of the cross-term $(\mathrm{HGR} \times \mathrm{MOR})$ of the real estate price change and proportion of mortgages in Model (5) is 0.02 , which is statistically significant.

Table 3. The result of panel regressions: lending growth (LG) as a performance measure.

\begin{tabular}{|c|c|c|c|c|c|}
\hline & Model (1) & Model (2) & Model (3) & Model (4) & Model (5) \\
\hline HGR & $\begin{array}{c}1.11^{* * *} \\
(8.27)\end{array}$ & $\begin{array}{c}0.89 * * * \\
(6.28)\end{array}$ & $\begin{array}{c}0.86^{* * *} \\
(6.16)\end{array}$ & $\begin{array}{c}0.80^{* * *} \\
(5.63)\end{array}$ & \\
\hline $\mathrm{HGR} \times \mathrm{MOR}$ & & & & & $\begin{array}{c}0.02^{* * *} \\
(5.42)\end{array}$ \\
\hline CALL & & $\begin{array}{c}1.14 \\
(1.48)\end{array}$ & & $\begin{array}{c}-0.77 \\
(-0.84)\end{array}$ & $\begin{array}{c}-0.94 \\
(-1.02)\end{array}$ \\
\hline GDPGR & & $\begin{array}{l}0.85^{* *} \\
(1.98)\end{array}$ & & $\begin{array}{l}0.75^{*} \\
(1.79)\end{array}$ & $\begin{array}{l}0.75 * \\
(1.79)\end{array}$ \\
\hline CPIGR & & $\begin{array}{c}0.23 \\
(0.35)\end{array}$ & & $\begin{array}{c}0.95 \\
(1.35)\end{array}$ & $\begin{array}{c}1.08 \\
(1.52)\end{array}$ \\
\hline CAPR & & & $\begin{array}{l}-0.77 * \\
(-1.86)\end{array}$ & $\begin{array}{c}-0.55 \\
(-1.19)\end{array}$ & $\begin{array}{c}-0.54 \\
(-1.16)\end{array}$ \\
\hline LOANR & & & $\begin{array}{l}-0.00 \\
(-0.02)\end{array}$ & $\begin{array}{c}0.03 \\
(0.23)\end{array}$ & $\begin{array}{l}-0.01 \\
(-0.08)\end{array}$ \\
\hline INR & & & $\begin{array}{c}0.21^{* * *} \\
(4.80)\end{array}$ & $\begin{array}{c}0.22^{* * *} \\
(4.30)\end{array}$ & $\begin{array}{c}0.24^{* * *} \\
(4.70)\end{array}$ \\
\hline LOANCONS & & & $\begin{array}{c}0.01 \\
(1.08)\end{array}$ & $\begin{array}{c}0.01 \\
(0.79)\end{array}$ & $\begin{array}{c}0.01 \\
(0.74)\end{array}$ \\
\hline$R^{2}$ & 0.414 & 0.468 & 0.523 & 0.533 & 0.529 \\
\hline
\end{tabular}

Note: ${ }^{* * *}, * *$ and $*$ denote significance at the $1 \%, 5 \%$, and $10 \%$ levels, respectively. $t$-values are in parentheses. 
Table 4. The result of regression: return on assets (ROA) as a performance measure.

\begin{tabular}{|c|c|c|c|c|c|}
\hline & Model (1) & Model (2) & Model (3) & Model (4) & Model (5) \\
\hline HGR & $\begin{array}{l}0.02 \text { ** } \\
(2.25)\end{array}$ & $\begin{array}{c}0.02 * * * \\
(2.60)\end{array}$ & $\begin{array}{c}0.01 \\
(1.29)\end{array}$ & $\begin{array}{c}0.01 \\
(0.75)\end{array}$ & \\
\hline $\mathrm{HGR} \times \mathrm{MOR}$ & & & & & $\begin{array}{c}0.00 \\
(0.44)\end{array}$ \\
\hline CALL & & $\begin{array}{c}-0.05 \\
(-1.02)\end{array}$ & & $\begin{array}{c}0.01 \\
(0.11)\end{array}$ & $\begin{array}{c}0.01 \\
(0.10)\end{array}$ \\
\hline GDPGR & & $\begin{array}{c}-0.06 \text { ** } \\
(-2.23)\end{array}$ & & $\begin{array}{l}-0.03 \\
(-1.21)\end{array}$ & $\begin{array}{c}-0.03 \\
(-1.18)\end{array}$ \\
\hline CPIGR & & $\begin{array}{l}0.11^{* *} \\
(2.42)\end{array}$ & & $\begin{array}{c}0.16^{* * *} \\
(3.52)\end{array}$ & $\begin{array}{c}0.16^{* * *} \\
(3.59)\end{array}$ \\
\hline CAPR & & & $\begin{array}{c}0.03 \\
(1.16)\end{array}$ & $\begin{array}{c}0.08^{* * *} \\
(2.67)\end{array}$ & $\begin{array}{c}0.08^{* * *} \\
(2.66)\end{array}$ \\
\hline LOANR & & & $\begin{array}{c}-0.01 \\
(-1.56)\end{array}$ & $\begin{array}{c}-0.01 \\
(-0.89)\end{array}$ & $\begin{array}{c}-0.01 \\
(-0.97)\end{array}$ \\
\hline INR & & & $\begin{array}{c}0.00 \\
(1.06)\end{array}$ & $\begin{array}{l}0.01^{*} \\
(1.92)\end{array}$ & $\begin{array}{c}0.01 * * \\
(2.02)\end{array}$ \\
\hline LOANCONS & & & $\begin{array}{c}-0.01 * * * \\
(-6.38)\end{array}$ & $\begin{array}{c}-0.01^{* * *} \\
(-5.84)\end{array}$ & $\begin{array}{c}-0.01 * * * \\
(-5.92)\end{array}$ \\
\hline $\mathrm{R}^{2}$ & 0.184 & 0.242 & 0.340 & 0.383 & 0.382 \\
\hline
\end{tabular}

Note: ${ }^{* * *}, * *$, and ${ }^{*}$ denote significance at the $1 \%, 5 \%$, and $10 \%$ levels, respectively. $t$-values are in parentheses.

Table 5. Results of regression: non-performing loans (NPL) as a performance measure.

\begin{tabular}{|c|c|c|c|c|c|}
\hline & Model (1) & Model (2) & Model (3) & Model (4) & Model (5) \\
\hline HGR & $\begin{array}{c}-0.02 \\
(-0.99)\end{array}$ & $\begin{array}{c}-0.08^{* * *} \\
(-3.92)\end{array}$ & $\begin{array}{c}-0.05^{* * *} \\
(-2.72)\end{array}$ & $\begin{array}{c}-0.05^{* * *} \\
(-2.91)\end{array}$ & \\
\hline $\mathrm{HGR} \times \mathrm{MOR}$ & & & & & $\begin{array}{c}-0.00 * * * \\
(-3.30)\end{array}$ \\
\hline CALL & & $\begin{array}{c}0.45^{* * *} \\
(4.24)\end{array}$ & & $\begin{array}{c}0.10 \\
(0.86)\end{array}$ & $\begin{array}{c}0.12 \\
(0.99)\end{array}$ \\
\hline GDPGR & & $\begin{array}{c}0.22 * * * \\
(3.76)\end{array}$ & & $\begin{array}{c}0.15^{* * *} \\
(2.70)\end{array}$ & $\begin{array}{c}0.15^{* * *} \\
(2.75)\end{array}$ \\
\hline CPIGR & & $\begin{array}{l}-0.18 * \\
(-1.93)\end{array}$ & & $\begin{array}{l}-0.16^{*} \\
(-1.69)\end{array}$ & $\begin{array}{l}-0.16^{*} \\
(-1.73)\end{array}$ \\
\hline CAPR & & & $\begin{array}{c}-0.02 \\
(-0.34)\end{array}$ & $\begin{array}{c}-0.04 \\
(-0.68)\end{array}$ & $\begin{array}{c}-0.04 \\
(-0.72)\end{array}$ \\
\hline LOANR & & & $\begin{array}{c}-0.04^{* * *} \\
(-2.86)\end{array}$ & $\begin{array}{c}-0.02 \\
(-1.58)\end{array}$ & $\begin{array}{c}-0.02 \\
(-1.49)\end{array}$ \\
\hline INR & & & $\begin{array}{c}0.02^{* * *} \\
(4.07)\end{array}$ & $\begin{array}{l}0.01 * * \\
(2.09)\end{array}$ & $\begin{array}{l}0.01^{* *} \\
(1.98)\end{array}$ \\
\hline LOANCONS & & & $\begin{array}{c}0.01^{* * *} \\
(6.58)\end{array}$ & $\begin{array}{c}0.01^{* * *} \\
(5.77)\end{array}$ & $\begin{array}{c}0.01^{* * *} \\
(5.67)\end{array}$ \\
\hline $\mathrm{R}^{2}$ & 0.298 & 0.515 & 0.592 & 0.618 & 0.622 \\
\hline
\end{tabular}

Note: ${ }^{* * *},{ }^{* *}$, and ${ }^{*}$ denote significance at the $1 \%, 5 \%$, and $10 \%$ levels, respectively. $t$-values are in parentheses.

Second, we report the impact of housing prices on bank profits in Table 4. In Model (1), which does not control for other factors, the coefficient of HGR has a statistically significant positive value, which remains applicable even after controlling for macroeconomic variables. However, the significance disappears after controlling for other factors that affect the bank profitability. Increase in housing prices does not explain bank profitability. Rather, CPI growth rate, CAPR, and loan constitution (LOANCONS) absorb the impact of HGR. Thus, bank profitability is not determined by real estate price changes; rather, banks with better funding capabilities and larger business loans are more profitable. 
Table 5 shows the impact of changes in real estate prices on the bad loan ratio. The result of Model (1) shows that the coefficient of HGR is negative but is not statistically significant. However, from the results of Model (4), the coefficient of HGR is -0.05 , which is statistically negatively significant at the $1 \%$ level. This is consistent with the results of previous studies [46,47]. Changes in real estate prices will affect the value of collateral, lowering the ratio of bad loans and improving the asset quality. In Model (5), HGR $\times$ MOR is statistically negatively significant at the $1 \%$ level. It can be inferred that these effects are differentiated according to the volume of mortgage loans. In the case of rising real estate prices, the higher the proportion of real estate mortgage loans, the lower the ratio of insolvent loans.

The magnitude and significance of the control variables are slightly different depending on which model is used and how bank performance is measured. Specifically, the higher the CAPR, the higher the loan growth rate; furthermore, profitability is improved. The better the capital adequacy, the lower the cost. LOANR has a negative impact on loan growth rate. The lower the risk exposure of banks, the higher the growth rate of bank lending. In general, it seems that loan assets are less liquid than government or corporate bonds with a high grade and have a high default risk. This means that if the volume of lending is too large, they cannot afford to increase the additional loans. Interest revenue (INR) has a positive impact on loan growth rate. The lower the interest revenue, the greater the loan growth rate. Higher interest revenue means the interest rate on loans is high, which indicates banks apply a high lending rate even if the credit or collateral risk is high. In this case, the profitability of the bank will increase, but the ratio of bad loans will also increase. Finally, the loan constitution (LOANCONS) has a different impact on bank profitability and bad loan ratio. If corporate loans are higher than household loans, profitability is lower and bad loan ratio is larger. Corporate loans is riskier than household loans because it is relatively easier to check what household borrowing is spent for; spending is mostly buying a home or purchasing durable goods. Generally, loans to corporations are large and uncertainty is high. Information asymmetry in lending is also significantly higher than household loans. As the volume of relatively risky corporate loans increases, the bad loan ratio increases.

\subsection{Time-Series Classification: By Real Estate Business Cycles}

In this section, we divide the entire sample period into downturn and upturn to confirm whether there are any differences in the results according to the real estate business cycles. In general, banks tend to screen loans more generously in the economic upswing. In addition, banks' excessive lending competition can lead to a decline in lending rates below the credit risk level. If the value of collateral assets slumps in a depressed period, the loan assets become insolvent and losses occur. Moreover, the deterioration in bank performance during a recession of the real estate business may be greater than the improvement in performance during a boom [51,52]. Therefore, we examine whether there is any difference in the effect of changes in housing prices on bank performance for the analysis period.

We use HP filters to determine the real estate cycle. The HP filter is a method of decomposing the economic time-series into long-term trend fluctuations and cyclic fluctuations. It can also extract long-term trend fluctuations using the spline smoothing method [53,54]. Previous studies analyzing Korean real estate cycles also use HP filters to determine the cycle of the housing business cycle. Figure 2 shows the cycle of the house price index applying the HP filter; there have been three cycles since 2000 .

The results of the regression analysis for each period are reported in Table 6. Panel A reports the results of the boom and Panel B reports the recession. We focus on the results of Model (4), which controlled for all variables. In the results, we capture two peculiar phenomena. First, banks increase loans when housing prices rise in a boom; it is statistically significant. If housing prices rise during a real estate boom, banks should be able to make positive lending decisions. Even if the borrower defaults, they can easily recover the loan. 


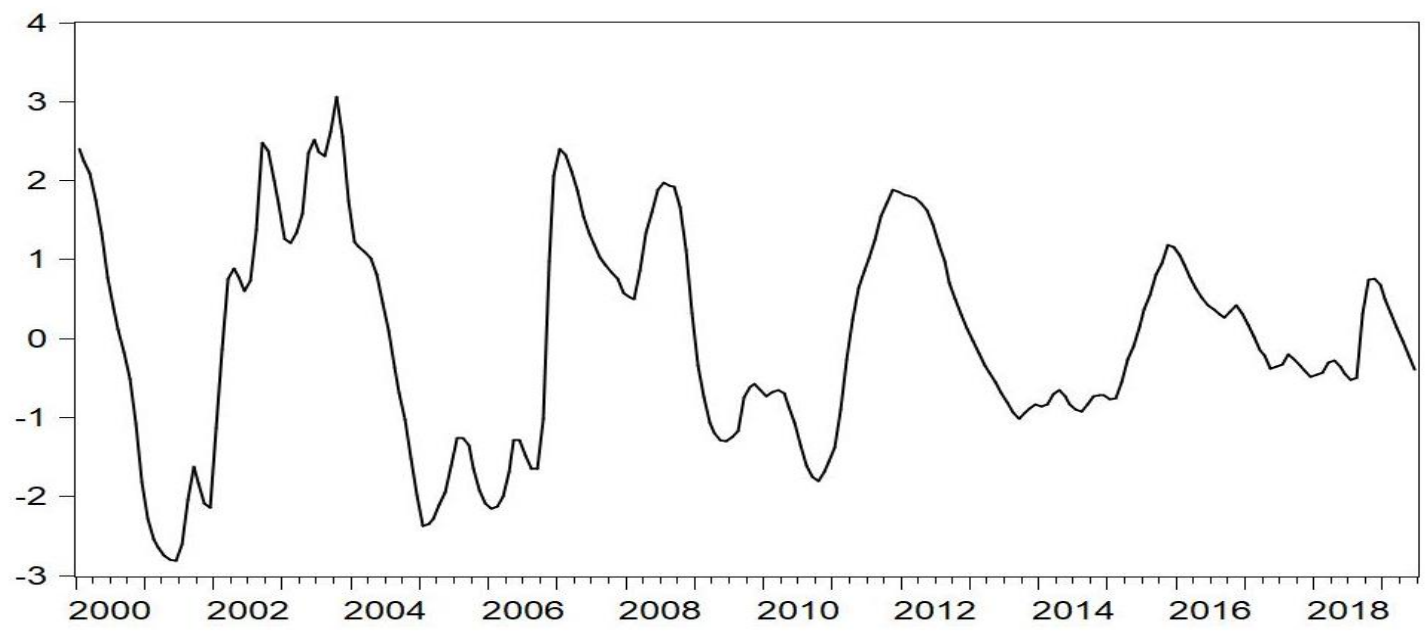

Figure 2. Real estate business cycles.

Table 6. The results of regression: by the real estate business cycles.

\begin{tabular}{|c|c|c|c|c|c|c|c|c|c|}
\hline & \multicolumn{3}{|c|}{ LG } & \multicolumn{3}{|c|}{ ROA } & \multicolumn{3}{|c|}{ NPL } \\
\hline & Model (2) & Model (3) & Model (4) & Model (2) & Model (3) & Model (4) & Model (2) & Model (3) & Model (4) \\
\hline \multicolumn{10}{|c|}{ Panel A: Boom } \\
\hline HGR & $\begin{array}{c}1.62 * * * * \\
(5.83)\end{array}$ & $\begin{array}{c}1.31^{* * * *} \\
(5.44)\end{array}$ & $\begin{array}{c}1.41^{* * *} \\
(4.68)\end{array}$ & $\begin{array}{c}-0.04^{* * *} \\
(-2.78)\end{array}$ & $\begin{array}{l}-0.01 \\
(-0.48)\end{array}$ & $\begin{array}{l}-0.01 \\
(-0.80)\end{array}$ & $\begin{array}{l}0.06^{*} \\
(1.94)\end{array}$ & $\begin{array}{l}-0.01 \\
(-0.33)\end{array}$ & $\begin{array}{c}0.03 \\
(1.05)\end{array}$ \\
\hline Controls & Yes & Yes & Yes & Yes & Yes & Yes & Yes & Yes & Yes \\
\hline$R^{2}$ & 0.652 & 0.671 & 0.706 & 0.389 & 0.264 & 0.486 & 0.322 & 0.389 & 0.435 \\
\hline \multicolumn{10}{|c|}{ Panel B: Recession } \\
\hline HGR & $\begin{array}{c}0.54 \\
(1.60)\end{array}$ & $\begin{array}{c}0.73 * * * \\
(2.91)\end{array}$ & $\begin{array}{c}0.54 \\
(1.57)\end{array}$ & $\begin{array}{l}-0.03 \\
(-1.27)\end{array}$ & $\begin{array}{l}-0.01 \\
(-0.37)\end{array}$ & $\begin{array}{c}-0.08 * * * \\
(-3.50)\end{array}$ & $\begin{array}{l}-0.02 \\
(-0.32)\end{array}$ & $\begin{array}{c}-0.05 \\
(-1.26)\end{array}$ & $\begin{array}{c}0.08 \\
(1.55)\end{array}$ \\
\hline Controls & Yes & Yes & Yes & Yes & Yes & Yes & Yes & Yes & Yes \\
\hline$R^{2}$ & 0.494 & 0.598 & 0.607 & 0.378 & 0.489 & 0.580 & 0.667 & 0.715 & 0.762 \\
\hline
\end{tabular}

Next, fluctuations in housing prices do not affect profitability during a boom. However, during a recession, fluctuations in housing prices have a negative effect on the bank profitability. This means bank profitability does not improve because of the lending competition in a real estate business boom; it suggests that profitability will deteriorate severely because of the deterioration of loan assets as new loans decline during a recession [17]. In addition, bank profitability may improve if housing prices rise in a recession.

\subsection{Cross-Sectional Classification: By Bank Type}

In this section, we divide banks into commercial and regional banks. The effect of housing price fluctuations may be different because regional banks are more focused on corporate loans than commercial banks. According to Davis and Zhu [9], the impact of real estate price fluctuations on bank performance may be different depending on the size of the bank as they may have different lending strategies and focus on different business lines.

Table 7 reports the results. The overall result is no different from the analysis of the entire sample. The main difference between commercial and regional banks is found in the bad loan ratio. In the case of regional banks, if housing prices fall, the bad loan ratio will be lower. Handling fewer mortgage loans implies they only make relatively less risky loans. 
Table 7. The results of regression: by bank type.

\begin{tabular}{|c|c|c|c|c|c|c|c|c|c|}
\hline & \multicolumn{3}{|c|}{ LG } & \multicolumn{3}{|c|}{ ROA } & \multicolumn{3}{|c|}{ NPL } \\
\hline & Model (2) & Model (3) & Model (4) & Model (2) & Model (3) & Model (4) & Model (2) & Model (3) & Model (4) \\
\hline \multicolumn{10}{|c|}{ Panel A: Commercial Bank } \\
\hline HGR & $\begin{array}{c}0.91^{* * * *} \\
(4.10)\end{array}$ & $\begin{array}{c}0.99 * * * \\
(4.59)\end{array}$ & $\begin{array}{c}0.91 * * * \\
(4.10)\end{array}$ & $\begin{array}{c}0.01 \\
(1.04)\end{array}$ & $\begin{array}{c}0.00 \\
(0.01)\end{array}$ & $\begin{array}{c}-0.01 \\
(-0.50)\end{array}$ & $\begin{array}{c}-0.07^{* *} \\
(-2.43)\end{array}$ & $\begin{array}{l}-0.04 \\
(-1.45)\end{array}$ & $\begin{array}{l}-0.04 \\
(-1.55)\end{array}$ \\
\hline Controls & Yes & Yes & Yes & Yes & Yes & Yes & Yes & Yes & Yes \\
\hline $\mathrm{R}^{2}$ & 0.539 & 0.607 & 0.621 & 0.285 & 0.397 & 0.425 & 0.581 & 0.735 & 0.740 \\
\hline \multicolumn{10}{|c|}{ Panel B: Regional Bank } \\
\hline HGR & $\begin{array}{l}0.88^{* * *} \\
(5.40)\end{array}$ & $\begin{array}{c}0.79 \text { *** } \\
(4.68)\end{array}$ & $\begin{array}{c}0.77 \text { *** } \\
(4.46)\end{array}$ & $\begin{array}{l}0.04 * * * \\
(2.70)\end{array}$ & $\begin{array}{c}0.02 \\
(1.61)\end{array}$ & $\begin{array}{c}0.02 \\
(1.57)\end{array}$ & $\begin{array}{c}-0.08^{* * *} \\
(-3.15)\end{array}$ & $\begin{array}{c}-0.06^{* *} \\
(-2.16)\end{array}$ & $\begin{array}{l}-0.06^{* *} \\
(-2.32)\end{array}$ \\
\hline Controls & Yes & Yes & Yes & Yes & Yes & Yes & Yes & Yes & Yes \\
\hline$R^{2}$ & 0.325 & 0.350 & 0.356 & 0.276 & 0.319 & 0.411 & 0.351 & 0.388 & 0.464 \\
\hline
\end{tabular}

\section{Conclusions}

This study analyzed the effects of housing price changes on bank lending decision and bank performance. Since banks not only have real estate as assets, but also directly provide mortgage loans, fluctuations in housing prices can directly affect the bank's soundness and profitability.

Major empirical results are summarized as follows. First, changes in housing prices affect bank lending decisions. Pro-cyclicality becomes more prominent in regional banks. In fact, the decline in housing prices is enough incentive for banks to reduce their loans. If housing prices fall, it will increase bad loans, which should add additional loan loss provision. Second, changes in housing prices affect banks' asset quality. If housing prices rise, banks' asset soundness will improve. As the value of collateral rises, the bad loan ratio (non-performing loans) is reduced. This is a consistent phenomenon regardless of the real estate business cycle. Third, changes in housing prices have a greater impact on bank profitability during real estate business recession than during booms. Because of the lending competition in a real estate business boom, bank profitability is unlikely to improve. However, profitability will deteriorate severely because of the deterioration of existing loan assets while new loans are decreasing during a recession. Therefore, be careful not to overload the loan when the housing market is in boom.

Korean households hold most of their assets as real estate. The proportion of real estate in the national household assets is higher than two-thirds. Therefore, it is very meaningful to analyze the relationship between housing prices and bank performance. It is worth investigating the systematic analysis of the relationship using data from individual bank levels rather than the entire banking industry and growth rate of the home price index proxy for housing price. However, because of the limitations in data availability, the analysis period begins from 2000. It is necessary to extend the research period with long-term data. In addition, real estate price fluctuations may vary by region because it is distributed throughout the country. Thus, it would be more meaningful to be able to utilize local real estate price data and local real estate loan information.

Author Contributions: The authors provided the following contributions to this paper. Y.O.: software, formal analysis, investigation, data curation, writing —original draft preparation; J.K.: methodology, investigation, writing-review and editing, supervision; Y.J.P.: methodology, funding acquisition, validation, writing-review and editing, project administration.

Funding: This research was supported by the Hallym University Research Fund, HRF-201910-006.

Conflicts of Interest: The authors declare no conflict of interest.

\section{References}

1. Zhang, D.; Cai, J.; Liu, J.; Kutan, A.M. Real estate investments and financial stability: evidence from regional commercial banks in China. Eur. J. Financ. 2018, 24, 1388-1408. 
2. Pan, H.; Wang, C. House prices, bank instability, and economic growth: Evidence from the threshold model. J. Bank. Financ. 2013, 37, 1720-1732.

3. Hott, C. Lending behavior and real estate prices. J. Bank. Financ. 2011, 35, 2429-2442.

4. Koetter, M.; Poghosyan, T. Real estate prices and bank stability. J. Bank. Financ. 2010, 34, 1129-1138.

5. Niinimäki, J.-P. Does collateral fuel moral hazard in banking? J. Bank. Financ. 2009, 33, 514-521.

6. Kiyotaki, N.; Moore, J. Credit Cycles. J. Polit. Econ. 1997, 105, 211-248.

7. Che, X.; Li, B.; Guo, K.; Wang, J. Property Prices and Bank Lending: Some Evidence from China's Regional Financial Centres. Procedia Comput. Sci. 2011, 4, 1660-1667.

8. McCarthy, J.; Peach, R.W. Are Home Prices the Next Bubble? Social Science Research Network: Rochester, NY, USA, 2004.

9. Davis, E.P.; Zhu, H. Commercial property prices and bank performance. Q. Rev. Econ. Financ. 2009, 49, 1341-1359.

10. Daglish, T. What motivates a subprime borrower to default? J. Bank. Financ. 2009, 33, 681-693.

11. Bernanke, B.; Gertler, M.; Gilchrist, S. The Financial Accelerator and the Flight to Quality. Rev. Econ. Stat. 1996, 78, 1-15.

12. Gerlach, S.; Peng, W. Bank lending and property prices in Hong Kong. J. Bank. Financ. 2005, $29,461-481$. [CrossRef]

13. Kim, K.-H. Housing and the Korean economy. J. Hous. Econ. 2004, 13, 321-341. [CrossRef]

14. Jung, J. The Interaction between Bank Lending and Housing Prices in Korea. J. Econ. Geogr. Soc. Korea 2013, 16, 631-646. [CrossRef]

15. Kim, D. Review and Implications of Changes in Real Estate Policy in Korea. Mon. Hous. Financ. Rep. 2013, 106, 4-19.

16. Chun, H.J. Liquidity-related Variables Impact on Housing Prices and Policy Implications. J. Econ. Geogr. Soc. Korea 2012, 15, 585-600.

17. Park, H.; Lee, S. Analysis of relationship between real estate price changes and bank management performance. 2006. Available online: http://www.bok.or.kr/viewer/skin/doc.html?fn=FILE_201803300723066901.pdf\&rs= /webview/result/P0000551/200603 (accessed on 24 May 2019).

18. Choi, E.-Y.; Koh, S.-S.; Hawang, H. An Analysis of the Effect of Change Real Estate Prices on the Bank. Hous. Stud. Rev. 2011, 19, 101-121.

19. Davis, E.P.; Zhu, H. Bank lending and commercial property cycles: Some cross-country evidence. J. Int. Money Financ. 2011, 30, 1-21. [CrossRef]

20. Blaško, M.; Sinkey, J.F. Bank asset structure, real-estate lending, and risk-taking. Q. Rev. Econ. Financ. 2006, 46, 53-81. [CrossRef]

21. Goodhart, C.; Hofmann, B. House prices, money, credit, and the macroeconomy. Oxf. Rev. Econ. Policy 2008, 24, 180-205. [CrossRef]

22. Markus, A.; Irena, G.; Andreas, I.; Franz, P. The influence of macroeconomic developments on Austrian banks: Implications for banking supervision. BIS Pap. 2001, 1, 91-116.

23. He, L.T.; Myer, F.C.N.; Webb, J.R. The sensitivity of bank stock returns to real estate. J. Real Estate Financ. Econ. 1996, 12, 203-220. [CrossRef]

24. Kauko, K. External deficits and non-performing loans in the recent financial crisis. Econ. Lett. 2012, 115, 196-199. [CrossRef]

25. Betz, J.; Krüger, S.; Kellner, R.; Rösch, D. Macroeconomic effects and frailties in the resolution of non-performing loans. 2017. Available online: https://www.sciencedirect.com/science/article/pii/S0378426617302224 (accessed on 24 May 2019).

26. Salas, V.; Saurina, J. Credit Risk in Two Institutional Regimes: Spanish Commercial and Savings Banks. J. Financ. Serv. Res. 2002, 22, 203-224. [CrossRef]

27. Louzis, D.P.; Vouldis, A.T.; Metaxas, V.L. Macroeconomic and bank-specific determinants of non-performing loans in Greece: A comparative study of mortgage, business and consumer loan portfolios. J. Bank. Financ. 2012, 36, 1012-1027. [CrossRef]

28. Bonin, J.P.; Hasan, I.; Wachtel, P. Bank performance, efficiency and ownership in transition countries. J. Bank. Financ. 2005, 29, 31-53. [CrossRef]

29. Petria, N.; Capraru, B.; Ihnatov, I. Determinants of Banks' Profitability: Evidence from EU 27 Banking Systems. Procedia Econ. Financ. 2015, 20, 518-524. [CrossRef] 
30. Albulescu, C.T. Banks' Profitability and Financial Soundness Indicators: A Macro-level Investigation in Emerging Countries. Procedia Econ. Financ. 2015, 23, 203-209. [CrossRef]

31. Căpraru, B.; Ihnatov, I. Banks' Profitability in Selected Central and Eastern European Countries. Procedia Econ. Financ. 2014, 16, 587-591. [CrossRef]

32. Pasiouras, F.; Kosmidou, K. Factors influencing the profitability of domestic and foreign commercial banks in the European Union. Res. Int. Bus. Financ. 2007, 21, 222-237. [CrossRef]

33. Kundid, A.; Škrabić, B.; Ercegovac, R. Determinants of bank profitability in Croatia. Croat. Oper. Res. Rev. 2011, 2, 168-182.

34. Anbar, A.; Alper, D. Bank Specific and Macroeconomic Determinants of Commercial Bank Profitability: Empirical Evidence from Turkey; Social Science Research Network: Rochester, NY, USA, 2011.

35. Trujillo-Ponce, A. What determines the profitability of banks? Evidence from Spain. Account. Financ. 2013, 53, 561-586. [CrossRef]

36. Cebula, R.J.; Koch, J.V.; Fenili, R.N. The Bank Failure Rate, Economic Conditions and Banking Statutes in the U.S., 1970-2009. Atl. Econ. J. 2011, 39, 39-46. [CrossRef]

37. Amos, O.M. The Regional Distribution of Bank Closings in the United States from 1982 to 1988. South. Econ. J. 1992, 58, 805-815. [CrossRef]

38. Drakos, K. Assessing the success of reform in transition banking 10 years later: An interest margins analysis. J. Policy Model. 2003, 25, 309-317. [CrossRef]

39. Fries, S.; Taci, A. Cost efficiency of banks in transition: Evidence from 289 banks in 15 post-communist countries. J. Bank. Financ. 2005, 29, 55-81. [CrossRef]

40. Berger, A.N. The Relationship between Capital and Earnings in Banking. J. Money Credit Bank. 1995, 27, 432-456. [CrossRef]

41. Kosmidou, K. The determinants of banks' profits in Greece during the period of EU financial integration. Manag. Financ. 2008, 34, 146-159. [CrossRef]

42. Dietrich, A.; Wanzenried, G. Determinants of bank profitability before and during the crisis: Evidence from Switzerland. J. Int. Financ. Mark. Inst. Money 2011, 21, 307-327. [CrossRef]

43. Angbazo, L. Commercial bank net interest margins, default risk, interest-rate risk, and off-balance sheet banking. J. Bank. Financ. 1997, 21, 55-87. [CrossRef]

44. Horváth, R. The Determinants of the Interest Rate Margins of Czech Banks. Czech J. Econ. Financ. 2009, 59, 128-136.

45. Molyneux, P.; Thornton, J. Determinants of European bank profitability: A note. J. Bank. Financ. 1992, 16, 1173-1178. [CrossRef]

46. Staikouras, C.K.; Wood, G.E. The Determinants Of European Bank Profitability. Int. Bus. Econ. Res. J. IBER 2004, 3, 57-68. [CrossRef]

47. Claeys, S.; Vander Vennet, R. Determinants of bank interest margins in Central and Eastern Europe: A comparison with the West. Econ. Syst. 2008, 32, 197-216. [CrossRef]

48. Demirgüç-Kunt, A.; Huizinga, H. Determinants of Commercial Bank Interest Margins and Profitability: Some International Evidence. World Bank Econ. Rev. 1999, 13, 379-408. [CrossRef]

49. Park, S.K.; Lee, H.S. A Comparison of Price Determinant between Residential and Commercial Properties. Korea Real Estate Rev. 2012, 22, 171-191.

50. Liang, Q.; Cao, H. Property prices and bank lending in China. J. Asian Econ. 2007, 18, 63-75. [CrossRef]

51. Berger, A.N.; Udell, G.F. The institutional memory hypothesis and the procyclicality of bank lending behavior. J. Financ. Intermediation 2004, 13, 458-495. [CrossRef]

52. Craig, R.S.; Davis, E.P.; Pascual, A.G. Sources of Procyclicality in East Asian Financial Systems. In Procyclicality of Financial Systems in Asia; Palgrave Macmillan: London, UK, 2006; pp. 55-123.

53. Hodrick, R.J.; Prescott, E.C. Postwar U.S. Business Cycles: An Empirical Investigation. J. Money Credit Bank. 1997, 29, 1-16. [CrossRef]

54. Baxter, M.; King, R.G. Measuring Business Cycles: Approximate Band-Pass Filters for Economic Time Series. Rev. Econ. Stat. 1999, 81, 575-593. [CrossRef]

(C) 2019 by the authors. Licensee MDPI, Basel, Switzerland. This article is an open access article distributed under the terms and conditions of the Creative Commons Attribution (CC BY) license (http://creativecommons.org/licenses/by/4.0/). 